\title{
IMPLEMENTASI MODEL PEMBELAJARAN PROBLEM SOLVING BERBASIS EKSPERIMEN PADA KONSEP LARUTAN ELEKTROLIT DAN NONELEKTROLIT
}

\author{
Chaerani Azizah, Dedi Irwandi, Tonih Feronika \\ Pendidikan Kimia, Jurusan Pendidikan Ilmu Pengetahuan Alam \\ FITK UIN Syarif Hidayatullah Jakarta, dedi.yuskar@gmail.com
}

\begin{abstract}
The aim of this research is to explore students' ability to solve problems through the implementation of problem-based learning through experiment. Students of grade X at SMA Negeri 9 Jakarta were given problem-based worksheet (LKS berbasis masalah) on the concept of electrolyte and non electrolyte solution. This research used descriptive method in which qualitative data from LKS was formulated into quantitative one. Students' skills on solving problems in LKS were shown from their ability to formulate hypothesis, determine the name and objectives of the experiment, develop procedure of the experiment, write the experiment data, draw a conclusion, make an abstract, and finish the experiment. Results of this research showed that in general students were categorized to have "good" and "very good" skills to solve problems.
\end{abstract}

Keywords: Problem Solving, Experiment, problem-based worksheet

\begin{abstract}
Abstrak
Penelitian ini bertujuan untuk memperoleh gambaran mengenai kemampuan siswa dalam memecahkan masalah yang tertuang dalam lembar kerja siswa (LKS) selama mengikuti kegiatan pembelajaran dengan menerapkan model pembelajaran problem solving berbasis eksperimen pada konsep larutan elektolit dan nonelektrolit. Subyek dalam penelitian ini adalah siswa kelas X di SMA Negeri 89 Jakarta tahun ajaran 2012/2013. Metode penelitian yang diterapkan adalah deskriptif. Perolehan data dilakukan dengan menggunakan instrumen lembar kerja siswa (LKS) untuk kemampuan memecahkan masalah. Analisis data untuk kemampuan memecahkan masalah yang tertuang dalam lembar kerja siswa (LKS) dengan nilai persentase. Kemampuan siswa dalam memecahkan masalah yang tertuang dalam lembar kerja siswa (LKS) yaitu kemampuan siswa dalam mengemukakan hipotesis, menentukan judul eksperimen, menentukan tujuan eksperimen, membuat prosedur kerja eksperimen, mencatat data pengamatan, membuat kesimpulan, membuat abstraksi, dan menyelesaikan tugas konsolidasi. Hasil penelitian yang diperoleh menunjukkan bahwa kemampuan siswa dalam memecahkan masalah dikategorikan sebagai baik dan sangat baik.
\end{abstract}

Kata kunci: Problem Solving, Eksperimen, LKS berbasis masalah

\section{PENDAHULUAN}

Kegiatan

pembelajaran

dalam implementasinya mengenal banyak istilah untuk menggambarkan cara mengajar yang akan dilakukan oleh guru. Saat ini, begitu banyak macam strategi, metode ataupun model pembelajaran yang bertujuan untuk meningkatkan kualitas pembelajaran menjadi lebih baik.

Guru merupakan penanggung jawab kegiatan proses pembelajaran di dalam kelas, sebab gurulah yang langsung memberikan kemungkinan bagi para siswa belajar dengan efektif melalui pembelajaran yang dikelolanya. Seperti yang telah kita ketahui, dalam keseluruhan proses pendidikan di sekolah pembelajaran merupakan aktivitas yang paling utama. Keberhasilan pencapaian tujuan pendidikan banyak tergantung pada bagaimana proses pembelajaran berlangsung. Pengelolaan proses pembelajaran yang baik dapat memfokuskan siswa kepada tujuan pembelajaran dengan hasil yang optimal.

Terkait dengan mata pelajaran kimia, bahwa pada umumnya pembelajaran yang digunakan masih berpusat pada guru (teacher centered). Pembelajaran dilakukan dengan metode ceramah dan tanya jawab masih mendominasi kegiatan belajar. Hal ini dijelaskan lebih rinci mengenai faktor penyebab kesulitan antara lain sebanyak 53\% siswa saja yang mempelajari materi pelajaran sebelum dan sesudah diajarkan; $76 \%$ siswa kesulitan akibat materi kimia bersifat abstrak dan banyak hitungan; metode ceramah masih mendominasi kegiatan belajar $72,73 \%$, dan penggunaan media masih minim $51,36 \%$ (Sholahuddin, 2011). Oleh karena itu, guru diharapkan kreatif dalam mengembangkan model pembelajarannya dengan berpusat pada siswa (student centered). 
Beberapa materi kimia disampaikan dengan menggunakan kegiatan eksperimen. Adapun model pembelajaran kimia yang selama ini dilakukan pada kegiatan eksperimen cenderung menyajikan semua hal yang berkaitan dengan eksperimen, dimulai dari petunjuk praktikum sampai alat-alat gelas yang dibutuhkan telah disediakan. Kegiatan eksperimen yang berpusat pada prosedur pelaksanaan eksperimen saja. Model tersebut kurang menumbuhkan semangat menggali pengetahuan, karena kepada siswa telah disajikan apa yang akan diperoleh dari eksperimen tersebut. Hal ini berbeda dengan tujuan pembelajaran sains yaitu melakukan penyelidikan. Sehingga, teori yang diberikan oleh guru tidak semua dipahami oleh siswa dengan hanya penerimaan konseptual saja.

Dalam hal ini, pembelajaran kimia pada konsep larutan elektrolit dan nonelektrolit dengan kompetensi dasar mengidentifikasi sifat larutan elektrolit dan nonelektrolit berdasarkan data hasil percobaan akan berlangsung secara optimal apabila dilakukan dengan melakukan eksperimen yang melibatkan aktivitas intelektual dan seluruh anggota tubuh serta alat indera digabungkan dalam satu peristiwa pembelajaran. Oleh karena itu, dibutuhkan model pembelajaran yang berifat konstruktivistik melalui model pembelajaran problem solving berbasis eksperimen.

Keragaman model pembelajaran selalu bermula dari keinginan untuk memenuhi kebutuhan siswa. Pengembangan model-model pembelajaran merupakan suatu upaya yang harus dipersiapkan dan dilakukan guru dalam kegiatan pembelajaran. Dalam hal ini, membelajarkan problem solving bertujuan untuk membangun para siswa sebagai pemecah masalah yang baik, maka mereka tidak hanya dipersiapkan untuk memiliki kemampuan berpikir sains melainkan juga kemampuan memecahkan masalah dengan percaya diri terhadap tantangan hidup yang dihadapinya (Rosbiono, 2007). Dengan begitu, model pembelajaran problem solving menuntut siswa untuk belajar lebih bermakna dan mendalam. Selain itu, menuntut siswa untuk bertanggung jawab membuat berbagai keputusan yang bukan sepenuhnya tanggung jawab guru dan bahan ajar seperti pada umumnya.

Model pembelajaran Problem Solving berbasis eksperimen memberikan permasalahan dan teknik penyelesaian permasalahan tersebut dilakukan dengan kegiatan eksperimen di laboratorium. Setelah permasalahan terpecahkan melalui kegiatan eksperimen, kemudian siswa melakukan diskusi kelompok untuk menyampaikan konsep yang telah ditemukan. Pembelajaran ini melibatkan domain kognitif, afektif, dan psikomotor secara terintegrasi. Hal ini dilakukan untuk mendapatkan gambaran penerapan model yang dikaitkan dengan kemampuan siswa dalam bereksperimen yang tertuang dalam Lembar Kerja Siswa (LKS). Dalam hal ini, peneliti mencoba mengimplementasikan model pembelajaran problem solving berbasis eksperimen pada konsep larutan elektrolit dan nonelektrolit yang merupakan materi kimia kelas $\mathrm{X}$ yang pembelajarannya dengan kegiatan eksperimen.

\section{METODE PENELITIAN}

Metode yang digunakan dalam penelitian ini adalah metode deskriptif, dengan metode ini peneliti berupaya untuk mendeskripsikan atau memberikan gambaran terhadap obyek yang diteliti, yaitu: bagaimana model pembelajaran problem solving berbasis eksperimen yang ditunjukkan siswa dalam melakukan eksperimen pada konsep larutan elektrolit dan nonelektrolit.

Penelitian deskriptif adalah suatu metode penelitian yang ditunjukan untuk menggambarkan fenomena-fenomena yang ada, yang berlangsung pada saat ini atau saat lampau. Penelitian ini tidak mengadakan manipulasi atau pengubahan pada variabel-variabel bebas, tetapi menggambarkan suatu kondisi apa adanya. Penggambaran kondisi bisa individual atau kelompok, dan menggunakan angka-angka (Sukmadinata, 2012).

Subyek dalam penelitian ini adalah siswa kelas X SMA 89 Jakarta Timur. Pemilihan subyek tersebut didasarkan atas kesesuaian bahwa materi kimia konsep larutan elektrolit dan nonelektrolit dengan kegiatan pembelajaran di laboratorium diberikan pada siswa kelas tersebut yang mengacu pada silabus mata pelajaran kimia SMA dalam KTSP.

Teknik pengumpul data untuk memperoleh kemampuan siswa dalam memecahkan masalah dilakukan melalui penilaian Lembar Kerja Siswa (LKS) berdasarkan jawaban-jawaban yang diberikan siswa pada setiap tahapan-tahapan problem solving. Pada penelitian ini data yang diperoleh diolah dengan langkah-langkah sebagai berikut: 1). Pengolahan data yang digunakan di lembar kerja siswa pada penelitian ini dengan menggunakan rating scale mengacu pada pedoman skoring pada setiap tahapan-tahapan problem solving. 2). Mengubah skor mentah ke dalam nilai 
persentase. Mengubah skor mentah yang didapatkan kedalam nilai persentase berdasarkan rumus. Kemudian dilakukan penggolongan tingkat kemampuan siswa berdasarkan kriteria (Purwanto, 2010), dan 3). Mengelompokkan nilai siswa kedalam kriteria. Hasil penilaian tersebut dapat diketahui seberapa besar kemampuan siswa dalam memecahkan masalah dengan menggunakan kategori kemampuan siswa yang dapat digolongkan pada kelompok sangat baik (skor 86-100), baik (skor 76-85), cukup (skor 60-75), kurang (skor 55$59)$, dan sangat kurang (skor $\leq 54$ ).

\section{HASIL DAN PEMBAHASAN}

Di bawah ini adalah data kemampuan siswa dalam memecahkan masalah pada setiap percobaan yang dilakukan. $\mathrm{X}_{1}$ adalah percobaan 1 dan $\mathrm{X}_{2}$ adalah percobaan 2 yang tertuang dalam lembar kerja siswa (LKS) yang dilakukan pada kegiatan eksperiman dengan percobaan yang berbeda.

Tabel 1. Nilai Kemampuan Siswa dalam Memecahkan Masalah

\begin{tabular}{lcc}
\hline \multirow{2}{*}{$\begin{array}{c}\text { Tahapan } \\
\text { Problem Solving }\end{array}$} & \multicolumn{2}{c}{ Nilai } \\
\cline { 2 - 3 } & $\mathbf{X}_{\mathbf{1}}$ & $\mathbf{X}_{\mathbf{2}}$ \\
\hline Mengemukakan hipotesis & 81,17 & 89,50 \\
Menentukan judul & 66,67 & 87,67 \\
Menentukan tujuan & 75,00 & 91,67 \\
Membuat prosedur kerja eksperimen & 72,00 & 97,00 \\
Mencatat data pengamatan & 100,00 & 75,00 \\
Membuat kesimpulan & 66,67 & 83,33 \\
Membuat abstraksi & 79,33 & 100,00 \\
Menyelesaikan tugas konsolidasi & 75,00 & 96,33 \\
Rata-rata & 76,98 & 90,07 \\
\hline
\end{tabular}

Berdasarkan Tabel 1 dapat dilihat bahwa nilai kemampuan siswa dalam memecahkan masalah yang tertuang dalam Lembar Kerja Siswa (LKS) untuk percobaan 1 dan 2 pada tahapan mengemukakan hipotesis sebesar 81,17 dan 89,50; menentukan judul eksperimen sebesar 66,67 dan 87,67; menentukan tujuan eksperimen sebesar 75,00 dan 91,67; membuat prosedur kerja eksperimen sebesar 72,00 dan 97,00; mencatat data pengamatan sebesar 100,00 dan 75,00; membuat kesimpulan sebesar 66,67 dan 83,33; membuat abstraksi sebesar 79,33 dan 100,00; dan menyelesaikan tugas konsolidasi sebesar 75,00 dan 96,33. Secara keseluruhan, nilai rata-rata kemampuan siswa dalam memecahkan masalah untuk percobaan 1 sebesar 76,98 dan percobaan 2 sebesar 90,07.

Pada penelitian ini dilakukan dua kali percobaan, yaitu percobaan pertama bertujuan untuk mengidentifikasi dan mengelompokkan sifat larutan elektrolit dan non elektrolit berdasarkan bentuk zat (padatan, lelehan, dan larutan) dan jenis zat (asam, basa, dan senyawa organik) dengan menggunakan alat uji elektolit, dan percobaan kedua bertujuan untuk mengidentifikasi larutan elektrolit berdasarkan perbedaan konsentrasi zat dengan menggunakan multimeter. Percobaan 1 dilakukan menggunakan alat uji eletrolit untuk mengidentifikasi larutan elektrolit dan nonelektrolitnya berdasarkan nyala lampu dan gelembung gas. Sedangkan percobaan 2 dilakukan menggunakan multimeter/ avometer untuk mengidentifikasi larutan elektrolit berdasarkan tegangan listrik (voltase) dan arus listrik (ampere) yang terukur.

Mengkaji dari hasil penelitian yang dilakukan untuk memperoleh gambaran dengan menganalisis kemampuan siswa dalam memecahkan masalah yang tertuang dalam lembar kerja siswa (LKS). Berdasarkan data yang ada, dapat dilihat bahwa hampir semua siswa dalam kelompoknya mampu menyelesaikan setiap tahapan problem solving dengan kategori baik dan sangat baik, yang ditunjukkan dengan perolehan nilai ratarata pada percobaan 1 dan percobaan 2 sebesar 76,98 dan 90,07 . Perolehan tersebut didapat dari kemampuan siswa dalam mengemukakan hipotesis, menentukan judul eksperimen, menentukan tujuan eksperimen, membuat prosedur kerja eksperimen, mencatat data pengamatan, membuat kesimpulan, membuat abstraksi, dan menyelesaikan tugas konsolidasi.

Kemampuan siswa dalam memecahkan masalah yang tertuang dalam lembar kerja siswa (LKS) pada percobaan 1 dapat disajikan dalam bentuk grafik sebagai berikut:

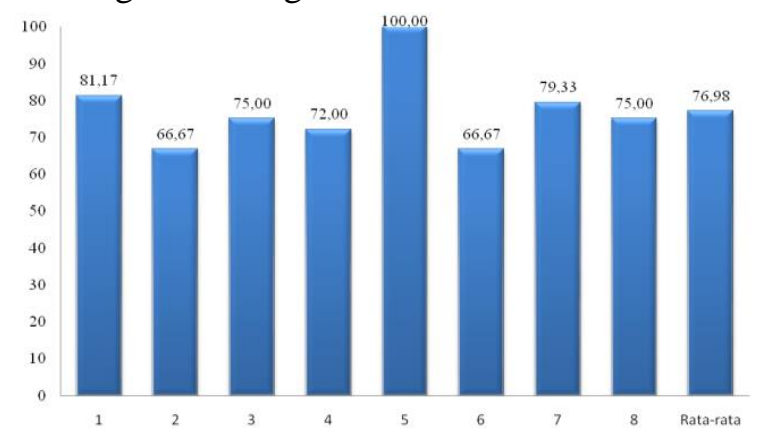

Gambar 1. Nilai Kemampuan Siswa dalam Memecahkan Masalah pada Percobaan 1, dengan 1) Mengemukakan Hipotesis; 2) Menentukan Judul Eksperimen; 3) Menentukan Tujuan Eksperimen; 4) Membuat Prosedur Kerja Eksperimen; 5) Mencatat Data Pengamatan; 6) Membuat Kesimpulan; 7) Membuat Abstraksi; 8) Menyelesaikan Tugas Konsolidasi 
Sedangkan, kemampuan siswa dalam memecahkan masalah yang tertuang dalam lembar kerja siswa (LKS) pada percobaan 2 dapat disajikan dalam gambar 2.

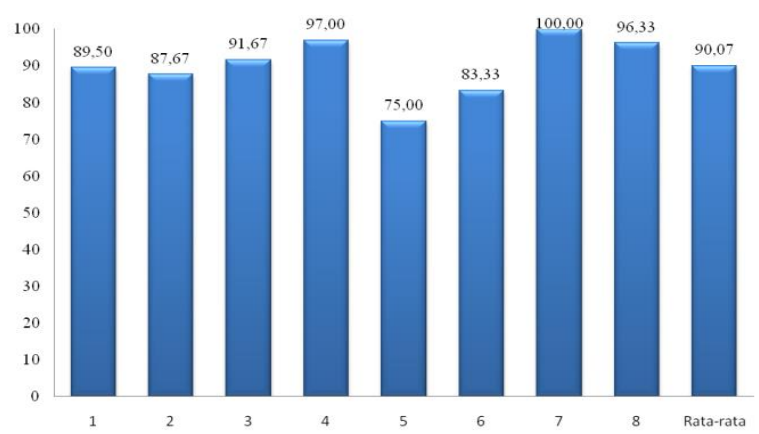

Gambar 2. Nilai Kemampuan Siswa dalam Memecahkan Masalah pada Percobaan 2, dengan 1) Mengemukakan Hipotesis; 2) Menentukan Judul Eksperimen; 3) Menentukan Tujuan Eksperimen; 4) Membuat Prosedur Kerja Eksperimen; 5) Mencatat Data Pengamatan; 6) Membuat Kesimpulan; 7) Membuat Abstraksi; 8) Menyelesaikan Tugas Konsolidasi.

Model pembelajaran problem solving berbasis eksperimen yang diterapkan pada konsep larutan elektrolit dan nonelektrolit berdasarkan tahapan problem solving. Tahapan problem solving yang dilakukan dalam pembelajaran akan memberikan gambaran mengenai kemampuan siswa dalam proses pembelajaran yaitu kemampuan siswa dalam memecahkan masalah. Hal ini sejalan dengan pendapat dibawah ini. Pemecahan masalah (problem solving) merupakan tujuan yang prinsipil dalam proses pembelajaran, khususnya di bidang sains dan teknologi, juga merupakan salah satu variabel penting yang mempengaruhi prestasi belajar siswa. Selain itu dengan pemecahan masalah dapat memeberikan kesempatan kepada siswa untuk menggambarkan sejumlah kemampuan dirinya (Purba, 2000).

Tahap mengemukakan hipotesis. Pada tahap ini, siswa dirangsang untuk berpikir secara mendalam yang membutuhkan penalaran. Hal ini sejalan dengan pendapat yang menyatakan bahwa tipe belajar ini diperlukan proses penalaran yang kadang-kadang memerlukan waktu yang lama, tetapi dengan tipe belajar problem solving ini kemampuan penalaran anak berkembang (Sagala, 2011). Hipotesis yang diberikan pada umumnya sesuai dengan konsep dan percobaan yang dilakukan. Siswa saling bertukar pikiran baik melalui diskusi kelompok maupun diskusi kelas.
Tahap menentukan judul eksperimen. Sebelum melakukan tahapan perencanaan dan konstruksi, siswa menentukan judul eksperimen yang akan dilakukannya. Judul eksperimen dapat ditentukan oleh siswa disebabkan adanya pengetahuan awal siswa mengenai konsep yang akan dipelajarinya melalui diskusi kelompok pada saat pelaksanaan pembelajaran.

Tahap membuat tujuan eksperimen. Berdasarkan judul eksperimen yang dibuat, maka siswa dapat menentukan tujuan eksperimen untuk percobaan yang akan dilakukannya. Dalam hal ini, kegiatan eksperimen yang dilakukan harus dapat menunjukkan secara jelas tujuan eksperimen yang akan dicapai. Penentuan tujuan ini sangat penting agar arah percobaan yang akan dilakukan tidak menyimpang dari tujuan semula.

Tahap membuat prosedur kerja eksperimen. Perencanaan dan konstruksi yang dilakukan dalam membuat prosedur kerja eksperimen merupakan keterampilan untuk memaparkan tahap demi tahap urutan kerja saat melakukan percobaan.

Setelah membuat prosedur kerja eksperimen, siswa dapat menentukan alat dan bahan yang dibutuhkan untuk melakukan eksperimen, karena mereka sudah mendapat gambaran percobaan yang akan dilakukan melalui prosedur kerja yang dibuat. Kemudian, siswa dapat melakukan eksperimen sesuai dengan rancangan eksperimen yang telah dibuat. Siswa melakukan percobaan mengenai larutan elektrolit dan nonelektrolit secara berkelompok, mengamati hal-hal yang terjadi selama percobaan, mencatat data hasil percobaan pada lembar kerja siswa (LKS) secara individu.

Selama kegiatan pembelajaran dengan melakukan percobaan, siswa mengalami secara langsung proses merancang alat uji dan melakukan eksperimen untuk membuktikan hipotesis yang telah diajukan.

Tahap mencatat data pengamatan. Setelah melakukan percobaan berdasarkan prosedur kerja yang dibuat, siswa diminta untuk melakukan pengamatan, kemudian mencatat data hasil pengamatan yang dilakukan. Kemampuan siswa menyajikan hasil pengamatan merupakan keterampilan siswa dalam memaparkan temuan yang didapatkan dari suatu percobaan. Pengamatan yang dilakukan siswa pada percobaan 1 dan 2 bertujuan untuk mengasah keterampilan siswa dalam menggunakan indera penglihatan dalam mengamati hasil percobaan yang dilakukan. 
Tahap membuat kesimpulan dan abstraksi. Siswa diminta menyimpulkan percobaan dan membuat abstraksi berdasarkan dari data pengamatan yang diperoleh dari hasil percobaan. Dalam hal ini, siswa lebih mampu membuat abstraksi dibanding dengan membuat kesimpulan. Abstraksi yang dibuat dalam bentuk generalisasi kesimpulan dari hasil percobaan.

Tahap menyelesaikan tugas konsolidasi pengetahuan. Tahap ini adalah tahap akhir dalam pembelajaran problem solving berbasis eksperimen. Siswa mengaitkan konsep larutan elektrolit dan nonelektrolit ke dalam bentuk peta konsep.

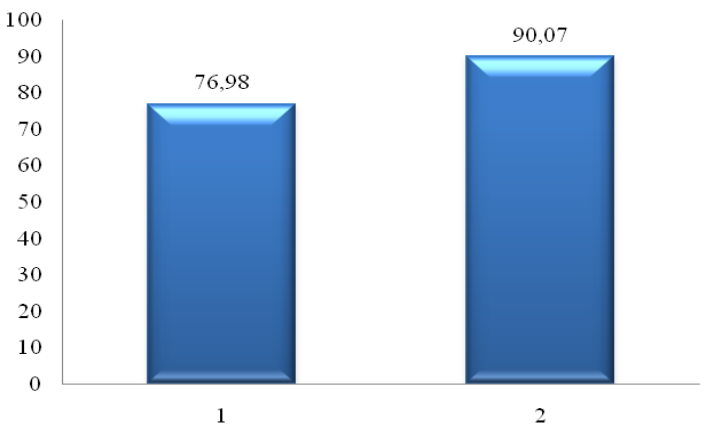

Gambar 3. Kemampuan Siswa dalam Memecahkan Masalah pada Percobaan 1 dan 2

Secara keseluruhan, kemampuan siswa dalam memecahkan masalah yang tertuang dalam lembar kerja siswa (LKS) pada percobaan 1 termasuk kedalam kategori baik dan pada percobaan 2 termasuk kedalam kategori sangat baik . Dari data yang dihasilkan, kemampuan siswa dalam memecahkan masalah pada percobaan 1 sebesar 76,98 yang termasuk kedalam kategori baik mengalami peningkatan pada percobaan 2 sebesar 90,07 yang termasuk kedalam kategori sangat baik.

Model pembelajaran problem solving berbasis eksperimen pada penelitian ini dapat menuntut siswa aktif dalam proses pembelajaran, sehingga dapat membangun siswa untuk menggunakan potensi dirinya lebih kreatif dalam mengembangkan kemampuan siswa dalam memecahkan masalah, yaitu: kemampuan siswa dalam mengemukakan hipotesis, menentukan judul eksperimen, menentukan tujuan, membuat prosedur kerja eksperimen, mencatat data pengamatan, membuat kesimpulan, membuat abstraksi, dan menyelesaikan tugas konsolidasi. Kegiatan eksperimen dilakukan dengan cara mempraktekan langsung untuk menguji atau membuktikan suatu konsep yang sedang dipelajari, yakni konsep larutan elektrolit dan nonelektrolit. Pengalaman yang dialami secara langsung dapat tertanam dalam ingatannya.

Kualitas kegiatan pembelajaran yang dilakukan sangat bergantung pada perencanaan dan pelaksanaan proses pembelajaran yang dilakukan guru. Pembelajaran yang berkualitas memerlukan pengembangan model-model pembelajaran yang tepat, sehingga pembelajaran menjadi lebih efektif dan efisien (Rusman, 2011). Dalam hal ini, tugas guru bukan semata-mata mengajar (teacher centered), tapi lebih kepada membelajarkan siswa (student centered). Seperti yang terjadi dalam penelitian ini, semua siswa antusias dalam melakukan eksperimen pada konsep larutan elektrolit dan nonelektrolit selama kegiatan pembelajaran, kerja kelompok antar siswa yang baik sehingga menghasilkan kemampuan siswa dalam memecahkan masalah yang tertuang dalam lembar kerja siswa (LKS) selama proses pembelajaran dengan kategori baik dan sangat baik pada percobaan 1 dan 2 .

\section{PENUTUP}

\section{Simpulan}

Hasil analisis dan pembahasan, dapat disimpulkan bahwa kemampuan siswa dalam memecahkan masalah yang tertuang dalam lembar kerja siswa (LKS) dengan menerapkan model pembelajaran problem solving berbasis eksperimen pada konsep larutan elekrolit dan nonelektrolit mendapatkan perolehan nilai pada percobaan 1 dan 2 sebesar 76,98 yang termasuk kategori baik dan 90,07 yang termasuk kategori sangat baik.

\section{Saran}

Berdasarkan penelitian yang telah dilakukan, maka saran yang dapat dikemukakan adalah Penelitian ini membuktikan bahwa penerapan model pembelajaran problem solving berbasis eksperimen berpengaruh positif terhadap kemampuan siswa dalam melakukan eksperimen, sehingga penerapan model pembelajaran problem solving berbasis eksperimen ini bisa menjadi alternatif model pembelajaran yang dapat diterapkan guru kimia pada konsep kimia yang melakukan eksperimen dalam upaya meningkatkan motivasi dan minat siswa selama proses pembelajaran.

Implementasi model pembelajaran problem solving berbasis eksperimen diperlukan persiapan yang baik, terutama dalam pembuatan perangkat pembelajaran. Selain itu harus memperhitungkan 
dengan baik untuk alokasi waktu pada saat melakukan percobaan dan pengisian lembar kerja siswa (LKS).

Pihak sekolah mampu memberikan masukkan dan dukungan bagi guru kimia di sekolah yang masih menggunakan model pembelajaran konvensional untuk dapat menerapkan berbagai model pembelajaran lain, seperti penerapan model pembelajaran problem solving berbasis eksperimen sebagai upaya meningkatkan motivasi dan minat siswa selama proses pembelajaran.

Saran peneliti untuk penelitian selanjutnya bagi mahasiswa kimia lain adalah meneliti secara lebih spesifik tentang model pembelajaran problem solving berbasis eksperimen.

\section{DAFTAR PUSTAKA}

Kadir, dkk. 2011. Pedoman Penulisan Skripsi. Jakarta: Fakultas Ilmu Tarbiyah dan Keguruan.

Majid A. 2005. Perencanaan Pembelajaran Mengembangkan Standar Kompetensi Guru. Bandung: PT Remaja Rosdakarya.
Purba JP. 2000. Pemecahan Masalah dan Penggunaan Strategi Pemecahan Masalah. Journal Invotec 1(1).

Purwanto MN. 2010. Prinsip-Prinsip dan Teknik Evaluasi Pembelajaran. Bandung: PT Remaja Rosdakarya.

Rosbiono M. 2007. Teori Problem Solving untuk Sains, Jakarta: Direktorat jenderal Peningkatan Mutu Pendidik dan Tenaga Kependidikan Depdiknas.

Rusman. 2011. Model-Model Pembelajaran Mengembangkan Profesionalisme Guru, Jakarta: Rajawali Pers.

Sagala S. 2011. Konsep dan Makna Pembelajaran. Bandung: Alfabeta.

Sholahuddin A. 2011. Pengembangan Buku Ajar Kimia Kelas X Berbasis Reduksi Didaktik: Uji Kelayakan di SMA Negeri Kota Banjarmasin. Jurnal Pendidikan dan Kebudayaan.

Sukmadinata NY. 2012. Metode Penelitian Pendidikan. Bandung: PT Remaja Rosdakarya. 